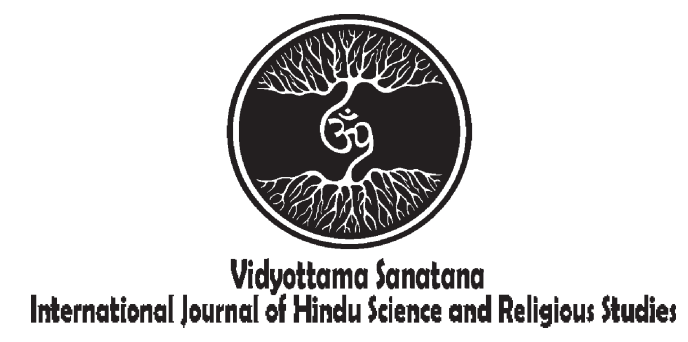

Vol. 1 No. 1 May 2017

\title{
The Value Of Saemaul Undong : South Korea Community Character Booster
}

\author{
By: \\ Kim Kim Min \\ The Academy of Korean Studies \\ e-mail: ssmkkm@hanmail.net
}

\begin{tabular}{|l|l|l|}
\hline Received: October 5, 2016 & Accepted: May 15, 2017 & Published: May 31, 2017 \\
\hline
\end{tabular}

\begin{abstract}
This research is motivated by the fact that many foreign companies are still have an orientation that a business is aimed at obtaining maximum profit by using capital as small as possible and justify any means. This is compounded by the fact that many of these companies make profits out of the occupied country without contributing towards the country. This condition triggers the urgency of the presence of the planting and preservation of good and strong character to nourish the existence of the company itself as well as the country they occupy. This study aims to reveal and define what and how the application of the teachings of Saemaul Undongas value in its implications for the development of values education. This study is designed using a qualitative approach with case study method. Data was collected by means of: observation, interview and document study. The results showed that the values of Saemaul Undongas become the spirit of good and strong character building which is basically built by the value of discipline, self-reliance and mutual cooperation. Implications of the study provides an overview to the Indonesian multiethnic that values the life of a powerful nation that should begin with the initial value that is the value of the next. In addition, it can be developed by the Public Education by trying to adopt and manipulate Saemaul Undongas training model for the value of diligent, independent, mutual cooperation and development in accordance with the needs of the desired value. Thus, from this article can be raised a proposition that "if countries want to move forward, then make the value in the life of the society as a reference".
\end{abstract}

Keywords : Saemaul Undongas, Good Character and Strong (Baku), Value Independence, of Mutual Cooperation and Discipline 


\section{Introduction}

The company is one of the important elements in the economic development of a country. Economic development can work well if the company has responsibilities to shareholders, employees, consumers, communities and the environment associated with the company's operations (Mulyadi, et al, 2012, p. 900). However, many of the foreign companies are only profiting from a state occupied without providing benefits for the country. This is due to corporate social responsibility (Corporate Social Responsibility) felt heavy and become the burden of foreign companies. So there is the assumption that business activities are dirty, containing deceit, and always siding with the strong (Gustina, 2008 , p. 146). Whereas business must go on as a profitable social communication for the parties involved (Bertens, 2000, p 17).

The situation is very worrying this very big and rich nation (read Indonesia). Most people just understand business is a business, which aims to generate as much profit as possible by using the smallest capital and get the most profit, so that the 'businessperson' justifies any means to make a profit, how to obtain raw materials, Where production, manpower, management, and marketing are done as effectively and as efficiently as possible. It makes businesspeople less likely to pay attention to social responsibility and ignore business ethics. In the end, business people start to abandon the prevailing norms and often do deviations that ultimately do not pay attention to the condition around it.

Indonesia as one of the developing countries that have high consumption power into the target of some foreign companies as a promising business opportunity, looks how the Indonesian people are very consumptive in terms of changing electronic goods like Mobile. It can not be denied how foreign electronic companies in Indonesia flocked to offer a variety of flagship products.
Indonesia as a developing country continues to improve its performance in attracting foreign companies to invest in Indonesia. The lack of employment opportunities for Indonesians makes Indonesians willing to work at any wage below the minimum wage (regional minimum wage). It can lead to irregularities, because the tendency of Indonesian society that consumerism make anyone willing to work anything in any way. This is starting to be addressed by foreign companies in developing the business with the perspective of the value of Saemaul Undong teachings. It is intended that workers who work in the company other than to work, they are also trained or familiarized in developing the good and strong character and value of Saemaul Undong teachings, which in the end the Indonesian people have good character and strong as the main capital in work.

\section{Results and Discussion}

\subsection{The idea of Saemaul Undong}

The word "Saemaul" comes from the word "sae", which means progressive reform based on past experience, the word "maul", referring to rural, regional and social society. Saemaul Undong can be literally interpreted as the New Village Movement (Park, 2002. pp. 4). Saemaul Undong can be defined as a new community movement where people work together to build better and wealthy villages. The Saemaul Undong movement is a movement intended to develop and modernize rural areas. This concept was introduced in 1971 when South Korea faced the problem of rural-urban disparity due to development priorities that always emphasized export-oriented industrialization. The aim is to raise the spirit of independence (indipendence), self-help (selfhelp) to realize the new village movement, and cooperation or mutual cooperation (Mutual 
Cooperation) in order to improve the living standards of local communities. The essence of Saemaul Undong is a form of development from below based on local initiative and participation. This activity is realized through the formation of local community cooperatives based on local initiatives, the utilization of labor and their materials and skills (Mochtar, 1996).

To reduce the economic disparity between the village and the city, President Park launched the New People Movement with the aim of enlightening the rural people through "new community education" to change the traditional views and behavior of ties and the poverty of the villagers, helping to develop crafts and savings, Cooperation and self-help, and modernizing rural communities (Darini, 2009, pp. 9).

First, Saemaul Undong greatly contributes to eradicate poverty, the effectiveness of development policies and support by the government creates harmony between the community and the government, resulting in cooperation between the two sides. Strategic government policies are able to motivate citizens to overcome poverty in their own way and effort. Second, Saemaul Undong carries out the modernization of rural communities by means of a comprehensive development approach. Saemaul Undong creates a new workplace that contributes to higher income for its people. Thirdly, Saemaul Undong has grown into a national movement thanks to its contribution in promoting a positive social atmosphere. Fourth, government policy through transition to export focus is driven by industrialization to sustain development along with agricultural and industrial sectors of agricultural productivity. Furthermore Saemaul Undong illustrates the continuing efforts of new and modern society in the future lives (Park, et al, 2002, p. 4).

In Saemaul Undong's idea there are 3 (three) kinds of interesting features as follows; (1) The movement is a soul/mental revolution.
(2) The movement is to improve the physical and social environment. (3) The movement is to increase the income and productivity of rural areas (Park, et al, 2002, p 7).

\subsection{Motivation of Saemaul Undong}

The first person to issue Saemaul Undong's idea was President Park Chuung-Hee on April 22, 1970 during a South Korean governor's meeting. He came from a poor farmer's son asking the local administration workers to provide a new rural development program that could attract attention and increase the spirit of village farmers and fishermen so they can learn about wisdom and help each other so that they create an independent community (Park, et al, 2002, p. 7). Saemaul's education is an essential component of the SU movement, in that it is able to foster discipline among rural populations, to awaken within it the three components of Saemaul spirit, and to educate them about the economic benefits of adopting modern agricultural and industrial technology (Bank, 2012, p. 16-17).

1. Training programs and methods;

Saemaul Education required all participants to remain in an isolated training camp together for a period of 1 week or even longer. Programs for a 1-week training camp of 105 hours, as well as an 11-day program consisting of 104 hours of instruction, are summarized in Boxes 1-3.

This educational program is designed to enhance participants' understanding of the moral aspect of Saemaul spirit, how and why local community development takes place, and how leadership Saemaul is established. Saemaul's education changed the overall attitude of the participants by leading them through the stimulus cycle, reflection, resolution, and practice.

Changes in mentality through education at the Training Institute for Saemaul, leaders initiated the Saemaul Undong campaign of 
frugality, social cleansing, and settlement in their families, neighborhoods, offices, and schools. Saemaul Undong is targeted to be able to change the mentality of society that will build civil society in urban environment and modernization based on rapid industrialization. Achieving this goal is necessary that the stereotypical mentality of selfishness and disorder must be reformed into altruism or individualism coupled with public responsibility and morality under the rule of law. To achieve this, the Saemaul Undong urban movement is targeted to collect three components of Saemaul's spirit (diligent, independent, and cooperative) as a means of building modern urban living ways such as the following (Bank, 2012 pp. 27-28): (1) moral order Practice of Saemaul Undong spirit, solidarity environment, creative application of traditional value, and public awareness) (2) Order behavior (obeying traffic rules, engaging in honest transactions, behaving according to public morality rules, and being punctual). (3) Environmental order (cleaning and home decoration, business enterprise, and roads, and greening the environment).

In the end, the change of mind set mentioned above made possible the concrete results of the Saemaul Undong movement which in turn enhanced the individual and the welfare community. These results may be summarized as follows (Kim, 2011; Ha, 2010): (1) Poverty reduction through rapid increase in household income. (2) Access to modern infrastructure and services is delivered in the form of mechanical agriculture, electrification, upgrading of housing, and health, most recently including seasonal farming nurseries. (3) Community empowerment through collecting social capital and simultaneous growth in civil society. (4) Revitalization of society through young leadership and enacted free status of village social life. (5) Elevation of women's role through increasing women's social participation and women's progress in the role of household management.

2. Objectives of Saemaul Undong;

Saemaul Undong's goal, first is to assist or facilitate the development and modernization of society. This notion leads not only to the improvement of individual life, but also to the whole life of the village community. The ultimate goal of Saemaul Undong's campaign is to promote the village, so that people can enjoy physical and spiritual well-being (Park, et al, 2002, pp. 4 and 8). Secondly, Saemaul Undong strives to ensure the integrity of social and individual trust levels, that integrity can begin when minimum physical needs can be met. Based on this belief, the campaign to improve the physical condition of life is the top priority of Saemaul Undoong (Park, et al, 2002, pp. 11).

Therefore, Edward (2010 pp. 7-9) states that Saemaul Undong is a positive national campaign stating the main program of the rural modernization government and the development and mobilization of each village, and almost every village, in Korea to participate. But this is not a shallow political dress.

The basic goal of Saemaul Undong is to advance the social state of society to be modern, comfortable and harmonious. (1) Strengthening efforts undertaken by workers and able to increase mutual pride, so as to maintain the growth rate has been achieved together and able to trust each other in the work environment. (2) Promote and keep the rhythm of work and public health, so that they are able to enjoy happiness and close relationships among their peers. (3) Building on an ongoing increase in the dignity of the nation, so everyone becomes proud as a citizen. Every society is subjected to state maturity, substantial economic development, and an established and moral consolation of culture (Park, et al., 2002, p. 12). Saemaul Undong's goal is to develop a 
prosperous society and ultimately develop a developed country using enormous energy from diligent, independent and mutual cooperation (Park, et al, 2002, pp. 12-13).

\section{Saemaul Undong in the Indonesian Context}

As mentioned earlier, Saemaul Undong implementation is implemented by taking a topdown and buttom-up system. This is also done by Indonesia in order to implement the values of Pancasila. The facts about the buttom-up system can be traced through the values of statehood and society contained in the precepts of Pancasila is not only a conceptual outcome of a person, but is a result of the great work of the Indonesian nation itself, lifted from the cultural values it possesses By the Indonesian nation itself through the process of philosophical reflection of the founders of the state (Kaelan, 2000. pp. 13). More assertive is that the origin of Pancasila is directly one of the origin of material (Kausa Materialist) which states that "the Indonesian nation is the origin of Pancasila values, ... which are excavated from the Indonesian nation in the form of cultural values and customs values - religious values contained in the daily life of the Indonesian nation ". (Notonegoro in Kaelan, 2012.p.47)

In addition, the implementation system of Pancasila values in a top-down manner is carried out in the way and the formal institution of the state by holding a BPUPKI session. In the re-discovery phase of Pancasila as the national identity, occurred at the first trial of BPUPKI which was held on May 29 until June 1, 1945. On June 1, 1945, before the session of BPUPKI, Ir. Soekarno mentions the five foundations for an independent Indonesia. Really Ir. Soekarno has proposed five precepts from the foundation of the state, he also offers another possibility, if one dislikes the number five, as well as the way he shows the basis of all the foundations of the five precepts. The alternative can be squeezed into Tri Sila can even be pursed again into Eka Sila. Tri Sila includes: socio-nationalism, socio democratie and deity. Meanwhile, Eka Sila explained by Ir. Soekarno namely "Gotong Royong", because according to Ir. Soekarno the Indonesian state that we founded should be a state of mutual cooperation (Latif, 2011. pp. 18-19). The statement at once answered that the value of gotong royong is more owned by Indonesia before it is implemented in Saemaul Undong value.

In addition, in the case of Pancasila economy as the basis of the state can be applied in the life of the nation, state, and society as follows: (1) Belief in the One, The wheel of the economy is driven by the economic, social and moral stimuli of God's teachings; (2) Just and Civilized Humanity There is a strong will of all societies to perfection of social equality (egalitarian), according to humanitarian principles that always seek prosperity; (3) Unity of Indonesia, The priority of economic policy is the creation of a robust national economy. This means that nationalism animates every economic policy in a Unity in Diversity society; (4) Citizenship led by Himat Wisdom in the Consultative/Representative. The cooperative is a pillar of economy and is a concrete form of mutual cooperation based on mutual cooperation; (5) Social Justice for All Indiesians. There is a clear and decisive balance between national-level planning and decentralization in the implementation of economic policy to achieve economic justice and social justice (Mubyarto in Oetojo and Alfian, 1993. pp. 240-241). In an economic system that describes the independence of the Indonesian people can be seen with the establishment of a cooperative as a pillar of the people's economy. In addition, the value of diligent or diligent is reflected in the economic policies based on the development of a strong regional economy through the development of SMEs (small and medium enterprises).

Thus it can be said, that there is a 
relationship of mutual influence-influence between society and its culture in this case the value embraced by the state and nation. If the culture of society and the state system is colored by the same soul, then the people and the country can live in harmony and happiness. However, if between the two elements there are differences, perhaps even contradictions, they will always suffer, frustrate, and feel tense (Soemardjan in Oesman and Alfian, 1993.p 172)

\section{Business Development in Saemaul Undong Perspective}

Saemaul Undong in an institutionalized establishment emerged as one of the important aspects of the Saemaul Undong movement with the opening of Seoul's Undema saemaul Council in August 1975, as a Non-Government Institution. In the early days of Saemaul Undong the company, aware of its essence as a nongovernmental institution, focused on conceptualising, productive workplaces and improvements in corporate environments and social service activities (Park, et al., 2002, pp. 117).

To establish a sense of love for the homeland and to increase the resilience of the work and the responsibility of the nation's development, the activities of the singing of national anthems, doing stretching exercises and publicizing the events that took place at the commemoration of Saemaul Week (Park, et al, 2002, P. 118).

The Saemaul Undong initiative of the company is also geared towards all the way towards understanding the sense of unity within the company to create a good working environment. Further movement encourages projects that are structured to eradicate social distrust and abuse of authority, to maintain open personnel management and improve penalty and reward systems (Park, et al., 2002, pp. 119). The company is geared toward helping and protecting mission people and unfortunate rewarding important notes in the variety and scale of its projects. Attention is given to helping co-workers who have experience in adverse conditions, and the various external activities undertaken (Park, et al., 2002, pp. 120).

\section{Conclusion}

The values that become the spirit of Saemaul Undong are basically built by the value of discipline, self-reliance, and mutual cooperation. It is already applied in the work culture in South Korea, where South Korean society recognizes that the importance of discipline is absolutely essential to continue working well. Then the value of self-reliance is equally important in building a good performance, where the value of independence is a thing that can make a person has a high fighting power, both for himself in public life.

\section{References}

Asian Development Bank. (2012). The Saemaul Undong Movement in the Republic of Korea, Sharing Knowledge on Community-Driven Development. Printed in the Philippines.

Aspin, D.N \& Chapman, J.D. (ed). 2007. Value Education and Lifelong Learning:Principles, Policies, Programmes. Neteherlands: Springer.

Bandura, A. (1969). Social-Learning Theory of Identificatory Processes in Goslin, D.A (ed). (1969). Handbook of Socialization Theory and Research. United States: Rand McNally \& Company.

Chan, R. K. H. (2006), 'Participatory Welfare in South Korea: Meaning and Issues', Center for Asian Pacific Studies, Working Paper Series No.174.

Chang Soo Choe. (2005). Key Factors To Successful Community Development: The Korean Experience. Japan: Institute of Developing Economics, JETRO. 
Kim, B.W. (2014). Samsung Code: 27 Prinsip Pengembangan Pribadi dan Organisasi ala Samsung; penerjemah Ria Febriyani. Jakarta: Noura Books.

Kim, C.Y. (2011). From Despair To Hope: Economic Policymaking in Korea 19451979. Seoul: Korea Development Institute.

Kim, D. K. (2005). The History of Korea. Westport, Connecticut: The Greenwood Press.

Kim, K.O. (2007), 'Inclusive Education in Korea', Country paper for the Regional Preparatory Workshop on Inclusive Education,

Koh, S.H. (2014). Why Samsung: Menginspirasi Dunia, Mencitakan Masa Depan. Penerjemah, Pradipta Nurmaya dan Renci. Yogyakarta: Bentang.

Kun, G. (2010). Saemaul (New Village) Undong in Korea - Factors of the Success and Their Transferability, SMU 40th Anniversary International Symposium. Key note speech.
Lickona, T. (2012). Educating For Character. Mendidik Untuk Membentuk Karakter. Remaja Rosda Karya. Bandung.

Lincoln, Yvonna S. and Guba, Egon G.(1985) .Naturalistic Inquiri. Sage Publications, Inc.

Park, S.Y. (2009). Analysis of Saemaul Undong: a Korean Rural Development Program in the 1970s. Asia-Pacific Development Journal.

Reed, E. (2010). Is Saemaul Undong a Model for Developing Countries Today? Anniversary of Saemaul Undong Hosted by the Korea Saemaul Undong Center.

Rho, W.J. (2013). Saemaul Undong of Korea: Generative Leadership and Emergence of the Social Value (in Korean), Seoul: Bubmoonsa.

Rho, Y. (2013). A Study on Coaching Leadership and Emergence of Innovative Behavior in Saemaul Undong, Seoul: Graduate School, Korea University. 